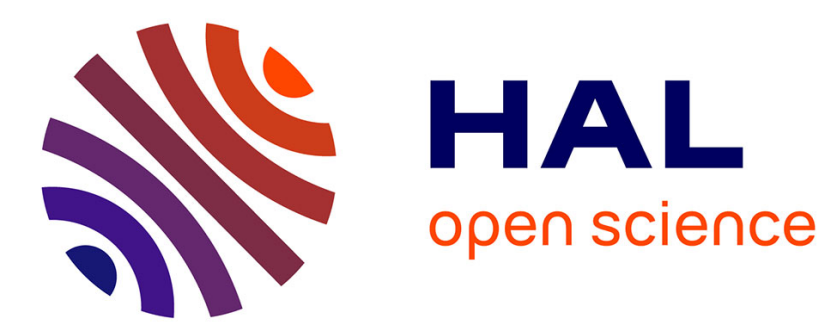

\title{
Activation of the hsp70 promoter by environmental inorganic and organic chemicals: relationships with cytotoxicity and lipophilicity.
}

\author{
S. Aït-Aïssa, J. M. Porcher, A. Arrigo, C. Lambré
}

\section{- To cite this version:}

S. Aït-Aïssa, J. M. Porcher, A. Arrigo, C. Lambré. Activation of the hsp70 promoter by environmental inorganic and organic chemicals: relationships with cytotoxicity and lipophilicity.. Toxicology, 2000, 145 (2-3), pp.147-57. ineris-00466292

\section{HAL Id: ineris-00466292}

\section{https://hal-ineris.archives-ouvertes.fr/ineris-00466292}

Submitted on 23 Mar 2010

HAL is a multi-disciplinary open access archive for the deposit and dissemination of scientific research documents, whether they are published or not. The documents may come from teaching and research institutions in France or abroad, or from public or private research centers.
L'archive ouverte pluridisciplinaire HAL, est destinée au dépôt et à la diffusion de documents scientifiques de niveau recherche, publiés ou non, émanant des établissements d'enseignement et de recherche français ou étrangers, des laboratoires publics ou privés. 
Activation of the $h s p 70$ promoter by environmental inorganic and organic chemicals: relationships with cytotoxicity and lipophilicity

S. Aït-Aïssa ${ }^{\mathrm{a}, *}, \mathrm{~J}-\mathrm{M}$. Porcher ${ }^{\mathrm{a}}$, A.-P. Arrigo ${ }^{\mathrm{b}}$, and C. Lambré ${ }^{\mathrm{a}}$

${ }^{a}$ Unité d'Evaluation des Risques Ecotoxicologiques, Institut National de l'Environnement Industriel et des Risques, BP2, 60550 Verneuil-en-Halatte, France and ${ }^{b}$ Laboratoire du Stress Cellulaire, Centre de Génétique Moléculaire et Cellulaire, Centre National de la Recherche Scientifique, UMR 5534, Université Claude Bernard Lyon-I, 69622 Villeurbanne, France.

Keywords: heat shock; hsp70 promoter; HeLa cells; organic pollutants; metals; lipophilicity.

Abbreviations: $\mathrm{B}(a) \mathrm{P}$, benzo(a)pyrene; CDNB, 1-chloro-2,4-dinitrobenzene; 4-CP, 4-chlorophenol; 3,4-DCA, 3,4-dichloroaniline; 2,4-DCP, 2,4-dichlorophenol; 2,4-D, 2,4-dichlorophenoxyacetic acid; 3,5-DCP, 3,5-dichlorophenol; HSE, heat shock element; HSF, heat shock transcription factor; PCP, pentachlorophenol; TCP, 2,4,5-trichlorophenol; TCHQ, tetrachlorohydroquinone.

* Corresponding author. Tel.:(33)344556511, fax:(33)344556604. E-mail address: selim.ait-aissa@ineris.fr. 


\begin{abstract}
Stress proteins (heat shock proteins; HSPs) have been proposed as general markers of cellular aggression and their use for environmental monitoring is often suggested. The aim of this work was to study the potency of various environmentally relevant organic and inorganic chemicals to induce the expression of the HSP70 marker. For this purpose, we used an established HeLa cell line containing the chloramphenicol acetyl transferase (CAT) gene under the control of the $h s p 70$ promoter. The screening of three metallic and fifteen organic chemicals revealed differences in their capacities to induce the $h s p 70$ promoter. The three metals tested (cadmium, zinc and mercury) were able to induce a stress response. Some organochlorine compounds (chlorophenol derivatives, tetrachlorohydroquinone, 3,4dichloroaniline, ethyl parathion and 1-chloro-2,4-dinitrobenzene) induced a response, whereas other common halogenated pesticides or aromatic hydrocarbons (e.g. benzo( $a$ )pyrene, 2,4dichlorophenoxyacetic acid, endosulfan, diuron, 4-nonylphenol) did not. The potency to induce $h s p 70$ was significantly correlated to the octanol-water partition coefficient $\left(\log \mathrm{K}_{o w}\right)$ of the inducing chemicals, except for 1-chloro-2,4-dinitrobenzeneand ethyl parathion. Cytotoxicity assays run in parallel to the induction measurements revealed that the 3 metals were effective at non cytotoxic doses whereas all organic compounds, except tetrachlorohydroquinoneand 1-chloro-2,4-dinitrobenzene, induced the promoter at cytotoxic doses. These results suggest that $h s p 70$ is induced by different mechanisms of toxicity. We propose that this model can be used in mechanistic studies for the detection of toxic effects of certain pollutants.
\end{abstract}




\section{Introduction}

A number of environmentally relevant physical and chemical agents are known to induce a set of cellular stress proteins, the heat-shock proteins (HSP) (Nover, 1991). In eukaryotes, regulation of $h s p$ gene expression is dependent on the activation of the heat shock transcription factor (HSF) (Morimoto, 1993). After shock, the release of HSF from its binding to HSP70 in the cytoplasm, allows formation of an HSF homotrimer which migrates to the nucleus and then binds the heat shock elements (HSE) in the promoter region of hsp genes, thus leading to the transcription activation of these genes. Although it is now admitted that the stressor-induced generation of misfolded proteins constitutes the trigger signal that up regulates the heat shock response (Ananthan et al., 1986; Hightower, 1991), there is still a lack of knowledge concerning the mechanisms of toxicity leading to these damages, and therefore to HSF activation, in particular in the case of organic pollutants.

For the last decade, much research has focused on the use of HSP as biomarker of aggression by environmental pollutants (reviewed by Sanders, 1993; Ryan and Hightower, 1996; Bierkens, 1998). Due to their conservation through evolution together with the wide diversity of their inducing agents and the numerous studies assessing the sensitivity of their synthesis in comparison to conventional endpoints such as growth, survival or reproduction, stress proteins have been proposed as sensitive markers of non-specific effects in environmental toxicity studies (Ryan and Hightower, 1996). However, due to discrepancies in published reports, their universal character is still a matter of controversy.

Whereas stress response (HSP response) has been extensively studied using a limited number of potent inducers such as heat, amino acid analogs or heavy metals, investigations on the use of HSP as biomarkers of environmental pollution exposure are, in contrast, of more recent development. The various available data on HSP induction in environmental toxicity studies lack cohesion because of differences between either the models (organisms or cellular) used, the different families of HSPs investigated, the methodology used for their detection, or the pollutants tested. In addition, some studies on the induction of HSP by organic pollutants have identified various compounds as non effective in different model systems using either organisms (Cochrane et al., 1991) or cells (Wiegant et al., 1994; Salminen et al., 1996; Dilworth and Timbrell, 1998) and this even at cytotoxic doses.

Due to the large diversity of its inducers, the cellular stress response is thought to be triggered by different mechanisms of toxicity, among which proteotoxicity would be the common link. A mechanism of induction by chemical stress can rely on perturbations of the cellular redox 
status level by either oxidative stress, ion homeostasis alterations or energy metabolism inhibitors (reviewed by Voellmy, 1996; Freeman et al., 1999). Such inducing agents may interact either directly or indirectly with cellular proteins and lead to thiol oxidation, proteinprotein disulfide bonding and therefore to destabilization of their structure (Voellmy, 1996). Similarly, recent results have suggested a relationship between the hepatic metabolisation of some hepatotoxicants by cytochrome $\mathrm{P} 450$, which generates reactive metabolites able to covalently bind proteins, resulting in HSP induction. These xenobiotic-protein adducts would be recognized by the heat shock system as non-native protein and thus activate the response (Salminen et al., 1996; Salminen et al., 1998). Besides, it has been reported that direct interactions between lipophilic organic chemicals (e.g. solvents, alcohols and phenols) and the hydrophobic core of proteins can lead to the destabilization of their structure and may be responsible for the induction of HSP synthesis (Meyer et al., 1995; Neuhaus-Steinmetz and Rensing, 1997). In these studies, stress protein induction was closely related to a decrease in cell survival, thus suggesting that the stress response elicited by these toxicants may be a secondary consequence of toxicological damages, following alteration of vital cellular functions, e.g. membrane-associated functions (Hahn et al., 1985).

Therefore, efforts are still needed to define the relevance of HSP induction as a toxicological endpoint, in particular, after exposure to organic pollutants. In this regard, in vitro systems are useful to elucidate the cellular mechanisms of toxicity leading to HSP induction that can occur in vivo. Among the different in vitro systems, models of cells carrying reporter genes present a growing interest due to their simplicity, rapidity and low-cost effectiveness (Fischbach et al., 1993; Van Dyk et al., 1994; Todd et al., 1995; Vincent et al., 1997).

In the present study, we have examined the effect of various environmental chemicals on the activation of the human $h s p 70$ gene. For this purpose, we used stably transfected HeLa cells carrying the human $h s p 70$ promoter linked to the chloramphenicol acetyl transferase (CAT) reporter gene (Kretz-Remy and Arrigo, 1994; Aït-Aïssa et al., 1999b). Different induction profiles were observed, as compared to the cytotoxic effects and the lipophilic characteristics (e.g. octanol-water partition coefficient) of the chemicals. 


\section{Materials and methods}

\subsection{Chemicals}

All chemicals were from Sigma Chemicals (France), except ethyl parathion (Promochem, France), 4-CP (Prolabo, France), 3,5-DCP (Aldrich, France) and 4-nonylphenol (Dr. Ehrenstorfer, Germany).

\subsection{Cell culture}

Stably transformed HeLa cells were cultured in Dulbecco's modified Eagle's medium (DMEM; Gibco, France) supplemented with 10\% heat inactivated fetal bovine serum (Gibco, France) and $1 \%$ antibiotics (penicillin-streptomycin) at $37^{\circ} \mathrm{C}$ in a humidified atmosphere containing $5 \% \mathrm{CO}_{2}$.

\subsection{Promoter induction experiments}

For induction experiments, cells were seeded onto 24-well plates (Costar) at a concentration of $2.10^{4}$ cells/well, and allowed to grow for 3 or 4 days until they reached $80 \%$ confluence. At this stage, the cells were washed twice with prewarmed phosphate buffer saline (PBS) before adding prewarmed serum-free culture medium containing the chemicals to be tested. All wells, including control cultures, received the same final concentration of the vehicle (ethanol or DMSO; never exceeding $0.1 \%$ ) used to solubilize the chemical. Stock solutions of toxicants were prepared ex temporarily. Cells were exposed for $5 \mathrm{hrs}$ or $16 \mathrm{hrs}$ at $37^{\circ} \mathrm{C}$, washed twice with complete medium and allowed to recover for the desired time prior to harvesting. Cells were then washed twice with cold PBS, lysed in $300 \mu 1$ of lysis buffer and $200 \mu 1$ of each lysate were analysed by using a CAT ELISA kit (Boehringer) according to the manufacturer's instructions. Results are expressed as the ratio between the amount of CAT detected and the total cellular protein content as determined by a modification of the Lowry's method (BioRad DC Protein Assay kit). Since cellular debris and floating cells are eliminated during the washing step, the measured CAT refers to the protein content of cells which are still adherent to the culture dishes. All the experiments were conducted with cells at up to 10 passages after transfection. At these passages, CAT expression in control cultures did not exceed the background levels of the ELISA assay. At higher passage numbers, some low levels of CAT protein appeared sporadically in untreated control cultures. This promoter 'leaking' was not further investigated, as this was not the scope of the present study. 


\subsection{Cytotoxicity}

Cytotoxicity was evaluated through two methodologies:

- Total protein contents were measured in exposed and control cultures (expressed as percentage of control) at the end of the induction experiments, as described above. Since the cell monolayers were subconfluent at the start of the experiment, the cytotoxic effect observed can be the reflect of either cellular growth inhibition or direct cell killing or both.

- The MTT (3-(4,5-dimethylthiazol-2-yl)-2,5-diphenyltetrazolium bromide) reduction test (Mossman, 1983) was used in preliminary experiments in order to set the concentrations of chemicals to be tested in HSP induction experiments. Cells were grown in 96-well microtiter plates until subconfluence and were then exposed to chemicals for $16 \mathrm{hrs}$ in serum-free medium. After exposure, the monolayers were washed with PBS and incubated for $3 \mathrm{hrs}$ at $37^{\circ} \mathrm{C}$ with $100 \mu 1$ of $0.5 \mathrm{mg} / \mathrm{ml}$ MTT dissolved in RPMI medium. MTT was removed and the formazan salt was solubilized in $100 \mu \mathrm{l}$ of isopropanol. Plates were read at $570 \mathrm{~nm}$ against a $660 \mathrm{~nm}$ reference wavelength on a microtiter reader (BioTek Instruments).

The effect on cell viability observed with the MTT test was further confirmed by a total protein assay performed at the end of the promoter induction experiments. Since a good correlation between MTT assay and total protein assay was observed (not illustrated), we have chosen to use total protein results as indicator of cytotoxicity.

\subsection{Statistical analysis}

Significant levels of $h s p 70$ promoter activation in treated cultures versus control cultures were determined by ANOVA (Dunett's test; TOXSTAT ${ }^{\mathrm{TM}}$ ). $\mathrm{p}<0.05$ was considered statistically significant.

\subsection{Octanol-water partition coefficent $\left(K_{\text {ow }}\right)$}

Values of coefficients were taken from Zhao et al. (1998) for 3,4-DCA, Babich and Borenfreund (1987) for PCP, TCP, 2,4-DCP, 4-CP, phenol, and Argese et al. (1999) for 3,5DCP. Values for TCHQ, CDNB and parathion ethyl were computer-calculated with the SRC LogKow v1.53 software. 


\section{Results}

3.1. Characterization of the induction of the hsp70 promoter by heat shock, cadmium and pentachlorophenol

The optimal experimental conditions to study $h s p 70$ activation by organic pollutants were determined, using heat stress and cadmium chloride, as positive controls for $h s p 70$ promoter induction, and PCP as an environmentally relevant organic model compound.

As seen in Figure 1, significant levels of CAT protein were detected in cultures treated either with a mild heat shock $\left(42^{\circ} \mathrm{C}\right)$ for $45 \mathrm{~min}$, or by exposure to $0.5 \mu \mathrm{M}$ cadmium dichloride or $100 \mu \mathrm{M}$ PCP for 16 hours. For all treatments, a recovery period of $24 \mathrm{hrs}$ was necessary to achieve complete processing of the marker protein. The response of the system to heat shock resulted more rapid ( $76 \%$ of the total amount of CAT synthesized after 6 hours of recovery) than to PCP $(66 \%)$ or $\mathrm{CdCl}_{2}(41 \%)$. It is worthwhile noting that no CAT production was detected immediately after the $16 \mathrm{hr}$ exposure to PCP, while significant amounts were seen at the same timepoint in the cultures treated with $\mathrm{CdCl}_{2}$. This observation could suggest an inhibitory effect on $h s p 70$ gene expression by PCP, which would be reversed on removal of the toxicant. Oppositely, a significant level of CAT was detected immediately after exposure to cadmium chloride, suggesting that this toxicant had no or limited inhibitory effect on gene expression.

As seen in Figure 2, induction of the $h s p 70$ promoter by each of the two chemical compounds was both time- and concentration-dependent. A long time exposure (16 hrs) to cadmium or PCP activated the $h s p 70$ gene at lower concentrations than after a short time exposure ( $5 \mathrm{hrs})$, both chemicals being more cytotoxic after $16 \mathrm{hrs}$. Since concentrations encountered in the environment are often very low, the use of a longer time of exposure appeared more adapted to further detect low amounts of pollutants.

\subsection{Induction by heavy metals}

Three metals were tested in order to evaluate the sensitivity of the system in HeLa cells toward this class of pollutants, as previously reported in other similar models (Fischbach et al., 1993; Todd et al., 1995). Cadmium dichloride, mercury dichloride and zinc sulfate induced the promoter at concentrations which had no effect on the cellular viability as determined by the total protein content (Table 1). Among them, cadmium was the strongest and the most specific as it induced a significant response at doses far below the cytotoxic ones. Zinc and mercury also induced a marked response in terms of amount of CAT produced. 


\subsection{Induction by various organic pollutants}

All organic chemicals were applied in serum-free medium for $16 \mathrm{hrs}$ and cellular CAT content was assessed after a 24 hour recovery period in serum containing culture medium. The results summarized in the Table 2 show that the tested toxicants exerted different effects on the activation of the $h s p 70$ promoter.

Among organic compounds, three different types of response were observed.

Some toxicants (TCHQ and CDNB) were able to activate the promoter at sublethal doses, although maximal induction occurred at a cytotoxic concentration. For other inducing chemicals, induction of the promoter was significant only at cytotoxic concentrations (chlorophenols compounds, 3,4-DCA, ethyl parathion). Eventually, 4-nonylphenol, endosulfan, diuron, $\mathrm{B}(a) \mathrm{P}$ and 2,4-D did not stimulate the promoter even if some of them appeared strongly cytotoxic at the tested concentrations. It is worthwhile noting that ethyl parathion appeared only weakly cytotoxic at the tested concentrations. At 250 and $500 \mu \mathrm{M}$, some problems of solubility occurred in the culture medium. This could explain its low toxicity, probably due to a lower bioavailability of the toxicant. However, at these concentrations, a weak but positive $h s p 70$ induction was observed. This was not true with $\mathrm{B}(a) \mathrm{P}$ which was also only weakly toxic and relatively non soluble at high concentrations.

\subsection{Relationships between hsp70 induction and lipophilicity}

The chlorophenols induced a positive response only at cytotoxic concentrations. The cytotoxicity as well as their potency on $h s p 70$ expression were related to the degree of chlorination of the molecules e.g. $\mathrm{PCP}>2,4,5-\mathrm{TCP}>3,5-\mathrm{DCP}>2,4-\mathrm{DCP}>4-\mathrm{CP}>$ phenol. In contrast to metal exposure, hsp70 induction was detected only at cytotoxic doses, suggesting that induction occurred through a non specific mechanism, probably through a narcotic process. This hypothesis was assessed by comparing the potency values of the inducing agents

- expressed as the ratio between the strength of the response (ngCAT/mg protein) and the concentrations at which this maximal response occurred - with the logarithmic value of their octanol/water partition coefficient ( $\log \mathrm{Kow}$ ), which reflect their hydrophobic properties. As seen in Figure 3, a significant linear correlation was obtained $\left(r^{2}=0.9503 ; p<0.001\right)$ for eight out of ten chemicals. This suggests that these chemicals may activate the $h s p 70$ promoter through a cellular mechanism of toxicity depending on hydrophobic interactions. TCHQ and 3,4-DCA also fitted into the correlation. In contrast, CDBN and ethyl parathion did not. This 
suggests that CDNB exerts its toxic effect through a more specific mechanism than a mere narcotic process, and appeared more toxic than its $\operatorname{logKow}$ would predict. In the case of ethyl parathion, the solubility problems encountered may have lead to misestimate its toxicity. This could explain why this chemical appeared less toxic than its logKow would predict.

\section{Discussion}

The various chemicals that we have tested showed differences in their capacities to induce the hsp70 promoter. This observation may therefore reveal different mechanisms of toxic action for $h s p$ induction.

Heavy metals were able to enhance the expression of the $h s p 70$ gene at sublethal concentrations. This has been already shown in many other cellular types (Fischbach et al., 1993; Ryan and Hightower, 1994) or organisms (Guven et al., 1994). Here, we have used this class of pollutants and heat shock treatment, as positive controls to confirm the sensitivity and the dose-effect relationship of the stress response in HeLa cells, and thus to validate the use of our cellular model toward well known hsp70 gene activators, in the detection of environmentally relevant toxic effects. Metals are known to interact with SH groups of proteins, through an oxidative action, and thus to alter them. This proteotoxic action may be one of their primary effects on the cell since a significant activation of $h s p 70$ is noticeable before cytotoxicity.

Three induction patterns were observed in response to organic compounds. Among the fifteen chemicals tested, eight (chlorophenols, 3,4-DCA and parathion) were effective at cytotoxic doses, two (TCHQ and CDNB) induced the $h s p 70$ promoter at apparently non toxic doses, and the five last chemicals $(2,4-\mathrm{D}, \mathrm{B}(a) \mathrm{P}$, 4-nonylphenol, endosulfan and diuron) induced no response, even at cytotoxic concentrations.

The chlorophenol derivatives, and, in a lesser extent, 3,4-DCA and parathion, induced the promoter at cytotoxic concentrations (Table 1). This suggests that, in these cases, the hsp70 activation is a secondary consequence of damages that affect cellular integrity. It can be supposed that these hydrophobic compounds may easily pass through plasmic membranes and alter vital cellular functions before interacting with cellular proteins, denaturing them and thus triggering a stress response. The significant correlation between the potency to induce $h s p 70$ and lipophilicity $\left(\log \mathrm{K}_{o w}\right)$ of the substances argues in this way. Similar results were reported in recent studies that have shown a strong correlation between stress protein expression, cytotoxicity, protein-denaturing ability and lipophilicity of alcoholic and phenolic compounds 
in C6 rat glioma cells (Neuhaus-Steinmetz and Rensing, 1997) and in the fungus Neurospora crassa (Meyer et al., 1995). Again, stress protein expression increased with a loss of cellular viability, as assessed by the neutral red uptake assay (Neuhaus-Steinmetz and Rensing, 1997). As discussed by the authors, the clear parallelism between HSP induction and proteindenaturing capacities of the alcohols studied versus their $\log \mathrm{K}_{o w}$, suggested that these compounds may interfere with the hydrophobic core of protein, thus leading to their denaturation by exposing the lipophilic moieties to the aqueous environment. Therefore, the generation of unfolded proteins would be the trigger for HSP expression. For this kind of toxicants, the heat shock response might be a consequence of primary lethal effects. It is likely that the same events occurred in our cellular model exposed to the chemicals that we have tested. Our findings, based on a quantitative induction assay which integrates the potency of a chemical on $h s p 70$ expression in terms of intensity of the response and of the effective concentration of the substance, show a similar dependence between lipophilicity and toxicity. With the chlorophenol family, a structure-activity correlation is demonstrated when comparing the toxic impact of chlorophenol with the level of chlorination. This observation is in agreement with previous reports on the cytotoxicity of these compounds in other in vitro systems (Babich and Borenfreund, 1987; Janik and Wolf, 1992; Zhao et al., 1995). These chemicals inhibit mitochondrial ATP production through the uncoupling of mitochondrial oxidative phosphorylations (MOP), and may therefore generate reactive oxygen radicals. However, as significant levels of $h s p 70$ promoter induction occurred only at concentrations which induced also a high degree of cytotoxicity, it cannot be excluded that the observed induction results from a different mechanism than the uncoupling of MOP. In addition, antioxidants such as $\mathrm{N}$-acetylcysteine or ascorbic acid did not modulate $h s p 70$ induction by PCP whereas it significantly reduced the induction by TCHQ and $\mathrm{CdCl}_{2}$ (Aït-Aïssa et al., 1999a), which are known to be oxidating chemical agents. This suggests that induction by PCP is not mediated by oxidative stress in HeLa cells.

The responses observed with TCHQ and CDNB were more sensitive. TCHQ is the major in vivo reactive metabolite of PCP when metabolised by the cytochrome P450. This toxicant is a known oxidative agent (Dahlaus et al., 1994) and is able to bind covalently cellular proteins and DNA (Van Ommen et al., 1986; Van Ommen et al., 1988). In addition to the hydrophobic nature of its toxicity (it fits in the $\operatorname{logKow}$ correlation), TCHQ may induce the promoter through oxidative interactions with cellular proteins, for the reasons described above. In HeLa 
cells, hsp70 induction by PCP may not depend on its transformation to TCHQ by microsomal cytochrome P450. The different induction patterns observed by these two chemicals suggests that they are effective through different pathways. In addition, the use of rat liver S9 mix in the culture medium reduced the activating effect of PCP on $h s p 70$ promoter (data not shown), thus suggesting that induction is due, at least partly, to the parent compound (PCP) and not to its metabolite, supporting the idea that this compound may act through direct hydrophobic interactions.

CDNB did not fit in the $\log \mathrm{K}_{o w}$ correlation. This compound is a known depletor of reduced glutathione (GSH). The correlation between oxidation of GSH and hsp gene activation has been demonstrated (Zou et al., 1998). It is likely that the specific effect of CDNB on the pool of cellular GSH is the main toxic mechanism by which this chemical induces the $h s p 70$ promoter.

No induction was detected with other pollutants such as 4-nonylphenol, endosulfan, diuron, $\mathrm{B}(a) \mathrm{P}$ and 2,4-D. In our experimental conditions, $\mathrm{B}(a) \mathrm{P}$ and 2,4-D showed a low cytotoxicity towards HeLa cells, in contrast to 4-nonylphenol, endosulfan or diuron which exerted a strong cytotoxicity. These negative results show that HSP70 alone cannot be considered as a general marker of toxicity. It can be argued that some of the non inducing toxicants, in particular $\mathrm{B}(a) \mathrm{P}$ and $2,4-\mathrm{D}$, need to be metabolised to exert their toxicity. $\mathrm{B}(a) \mathrm{P}$ was unable to induce any hsp70 expression in stably transfected HepG2 cells (Todd et al., 1995), which possess known competence for xenobiotic metabolism. On the contrary, this toxicant induced a transient HSP70 protein expression in vivo in the isopod Oniscus asellus (Kohler et al., 1999) and in primary cultures of salmon hepatocytes (Grosvik and Goksoyr, 1996). It is likely that transfected HeLa cells do not metabolise $\mathrm{B}(a) \mathrm{P}$ in our experimental conditions. In order to test if metabolisation of this compound could lead to an activation the $h s p 70$ promoter, we added commercial rat liver S9 mix in the culture medium either before or during exposure of HeLa cells to $\mathrm{B}(a) \mathrm{P}$, but no hsp70 induction nor enhanced cytotoxicity was observed (data not shown). It seems that extracellular metabolisation of $\mathrm{B}(a) \mathrm{P}$ is not sufficient to activate it. To our knowledge, no effect of 2,4-D, 4-nonylphenol, endosulfan or diuron on stress protein induction in eukaryotes has been reported so far. Only 2,4-D was able to induce the dnaK (bacterial analogue of HSP70) promoter in a dnaK::lux transformed Escherichia coli strain (Van Dyk et al., 1994). The fact that our experiments did not corroborate this observation 
stresses the concept that the heat shock response may be specific of the cell type or the organism considered.

In summary, the relationships between $h s p 70$ induction and the cytotoxic effect show that, for certain organic chemicals, the heat shock response occurs under conditions which constrain cell metabolism, and therefore does not represent a sensitive marker of toxicity in comparison to classical cell survival assays. However, it gives more detailed information about the mechanism of toxicity involved, as different patterns of hsp70 induction were observed. Moreover, the good agreement of our data with previous results showing a dependence between HSP response and lipophilicity of some chemical stressors (Hahn et al., 1985; Meyer et al., 1995; Neuhaus-Steinmetz and Rensing, 1997) strengthens the suitability of such a hsp 70-reporter gene cell line for the characterisation of the stress response in toxicity studies, and especially in mechanistic studies. Works, using other molecular endpoints (low molecular weight HSPs, cytochrome P450) and some modulators of hsp70 induction such as antioxidants or metabolic inhibitors, are in progress to study the mechanism of induction of stress by PCP in HeLa cells.

Finally, the simplicity of the assay should allow its use in screening programs for the detection of certain classes of pollutants such as heavy metals or some organochlorine compounds in environmental samples. However, the system used needs further validation studies to be carried out by comparing in vitro hsp70-CAT results with standardised tests that measure in vivo ecotoxicity endpoints. This approach is currently under evaluation in our laboratory.

\section{Acknowledgements:}

We wish to thank Dr C. Kretz-Rémy, who established the cell line, for her kind collaboration. We also would like to thank Dr M. Fischbach (Technologie du Promoteur de Stress cellulaire (TPSc), Paris, France) for his critical reading of the manuscript, and Prof. J-C. Murat (Paul Sabatier University, Toulouse, France) for helpful and stimulating discussions. This work was supported by a doctoral fellowship from the Agence de l'Environnement et de la Maîtrise de l'Energie to S.A.

\section{References}

Aït-Aïssa, S., Porcher, J.-M., Arrigo, A.-P., Lambré, C., 1999a. Involvement of an oxidative action in $h s p 70$ promoter induction by three selected environmental pollutants: protective 
effect of N-acetylcysteine. Abstracts of the XXXVII European Congress of Toxicology, EUROTOX'99, Oslo. Toxicol. Lett., 109 (supplement 1), 40.

Aït-Aïssa, S., Porcher, J.-M., Kretz-Rémy, C., Velarde, G., Arrigo, A.-P., Lambré, C., 1999b. Induction of the $h s p 70$ gene promoter by various anticancer drugs. Toxicol. In Vitro, 13, 651-655.

Ananthan, J., Goldberg, A.L., Voellmy, R., 1986. Abnormal protein serve as eukaryotic stress signals and trigger the activation of heat shock genes. Science, 232, 522-524.

Argese, E., Bettiol, C., Giurin, G., Miana, P., 1999. Quantitative structure-activity relationships for the toxicity of chlorophenols to mammalian submitochondrial particles. Chemosphere, 38, 2281-2292.

Babich, H., Borenfreund, E., 1987. In vitro cytotoxicity of organic pollutants to bluegill sunfish (BF-2) cells. Environ. Res., 42, 229-237.

Bierkens, J.G.E.A., 1998. Heat-shock proteins in ecotoxicological risk assessment. In: Reiss, C. et al. (Eds), Advances in Molecular Toxicology. VSP Int. Science Press, Zeist, Holland, pp. 531-544.

Cochrane, B.J., Irby, R.B., Snell, T.W., 1991. Effect of copper and tributyltin on stress protein abundance in the rotifer Brachionus plicatilis. Comp. Biochem. Physiol. C, 98, 385-390.

Dahlaus, M., Almstadt, E., Appel, K.E., 1994. The pentachlorophenol metabolite tetrachloro$p$-hydroquinone induces the formation of 8-hydroxy-2-deoxyguanosine in liver DNA of male B6C3F1 mice. Toxicol. Lett., 74, 265-274.

Dilworth, C., Timbrell, J.A., 1998. An investigation into the sensitivity of heat shock proteins as markers of cellular damage: a comparative study of hydrazine and cadmium chloride in primary rat hepatocyte culture. Biomarkers, 3, 177-190.

Fischbach, M., Sabbioni, E., Bromley, P., 1993. Induction of the human growth hormone gene placed under human hsp 70 promoter control in mouse cells: a quantitative indicator of metal toxicity. Cell Biol. Toxicol., 9, 177-188.

Freeman, M.L., Borrelli, M.J., Meredith, M.J., Lepock, J.R., 1999. On the path to the heat shock response: destabilization and formation of partially folded protein intermediates, a consequence of protein thiol modification. Free Rad. Biol. Med., 26, 737-745.

Grosvik, B.E., Goksoyr, A., 1996. Biomarker protein expression in primary cultures of salmon (Salmo salar L.) hepatocytes exposed to environmental pollutants. Biomarkers, 1, 45-53.

Guven, K., Duce, J.A., De Pomerai, D.I., 1994. Evaluation of a stress-inducible transgenic nematode strain for rapid aquatic toxicity testing. Aquatic Toxicol., 29, 119-137.

Hahn, G.M., Shiu, E.C., West, B., Goldstein, L., Li, G., 1985. Mechanistic implications of the induction of thermotolerance in Chinese hamster cells by organic solvents. Cancer Res., 45, 4138-4143.

Hightower, L.E., 1991. Heat shock, stress proteins, chaperones, and proteotoxicity. Cell, 66, 191-197.

Janik, F., Wolf, H.U., 1992. The Ca2+-transport-ATPase of human erythrocytes as an in vitro toxicity test system - Acute effects of some chlorinated compounds. J. Appl. Toxicol., 12, 351-358.

Kohler, H.R., Knodler, C., Zanger, M., 1999. Divergent kinetics of hsp70 induction in Oniscus asellus (Isopoda) in response to four environmentally relevant organic chemicals (B[a]P, PCB52, gamma-HCH, PCP): Suitability and limits of a biomarker. Arch. Environ. Contam. Toxicol., 36, 179-185.

Kretz-Remy, C., Arrigo, A.-P., 1994. The kinetics of HIV-1 long terminal repeat transcriptional activation resemble those of hsp70 promoter in heat-shock treated HeLa cells. FEBS Lett., 351, 191-196. 
Meyer, U., Schweim, P., Fracella, F., Rensing, L., 1995. Close correlation between heat shock response and cytotoxicity in Neurospora crassa treated with aliphatic alcohols and phenols. Appl. Environ. Microbiol., 61, 979-984.

Morimoto, R.I., 1993. Cell in stress: transcriptional activation of heat shock genes. Science, 259, 1409-1410.

Mossman, T., 1983. Rapid colorimetric assay for cellular growth and survival: application to proliferation and cytotoxicity assays. J. Immunol., 65, 55-63.

Neuhaus-Steinmetz, U., Rensing, L., 1997. Heat shock protein induction by certain chemical stressors is correlated with their cytotoxicity, lipophilicity and protein-denaturating capacity. Toxicology, 123, 185-195.

Nover, L., 1991. Heat Shock Response. CRC Press, Boca Raton, FL.

Ryan, J.A., Hightower, L.E., 1994. Evaluation of heavy-metal ion toxicity in fish cells using a combined stress protein and cytotoxicity assay. Environ. Toxicol. Chem., 13, 1231-1240.

Ryan, J.A., Hightower, L.E., 1996. Stress proteins as molecular biomarkers for environmental toxicology. In: Feige, U., Morimoto, R.I., Yahara, I., Polla, B. (Eds.), Stress-Inducible Cellular Responses, Birkhäuser Verlag Basel, Switzerland, pp. 411-424.

Salminen, W.F., Voellmy, R., Roberts, S.M., 1996. Induction of hsp70 in HepG2 cells in response to hepatotoxicants. Toxicol. Appl. Pharmacol., 141, 117-123.

Salminen, W.F., Voellmy, R., Roberts, S.M., 1998. Effect of N-acetylcysteine on heat shock protein induction by acetaminophen in mouse liver. J. Pharmacol. Exp. Ther., 286, 519524.

Sanders, B.M., 1993. Stress proteins in aquatic organisms: an environmental perspective. Crit. Rev. Toxicol., 23, 49-75.

Todd, M.D., Lee, M.J., Williams, J.L., Nalezny, J.M., Gee, P., Benjamin, M.B., Farr, S.B., 1995. The CAT-Tox (L) assay: a sensitive and specific measure of stress-induced transcription in transformed human liver cells. Fundam. Appl. Toxicol., 28, 118-128.

Van Dyk, T.K., Majarian, W.R., Konstantinov, K.B., Young, R.M., Dhurjati, P.S., Larossa, R.A., 1994. Rapid and sensitive pollutant detection by induction of heat shock genebioluminescence gene fusions. Appl. Environ. Microbiol., 60, 1414-1420.

Van Ommen, B., Adang, A., Müller, F., Van Bladeren, P.J., 1986. The microsomal metabolism of pentachlorophenol and its covalent binding to protein and DNA. Chem.Biol. Interact., 60, 1-11.

Van Ommen, B., Voncken, J.W., Müller, F., Van Bladeren, P.J., 1988. The oxidation of tetrachloro-1,4-hydroquinone by microsomes and purified cytochrome P-450b. Implications for covalent binding to protein and involvement of reactive oxygen species. Chem.-Biol. Interact., 65, 247-259.

Vincent, R., Goegan, P., Johnson, G., Brook, J.R., Kumarathasan, P., Bouthillier, L., Burnett, R.T., 1997. Regulation of promoter-CAT stress gene in HepG2 cells by suspensions of particles from ambiant air. Fundam. Appl. Toxicol., 39, 18-32.

Voellmy, R., 1996. Sensing stress and responding to stress. In: Feige, U., Morimoto, R.I., Yahara, I., Polla, B. (Eds.), Stress-Inducible Cellular Responses, Birkhäuser Verlag Basel, Switzerland., pp. 121-137.

Wiegant, F.A.C., Souren, J.E.M., van Rijn, J., van Wijk, R., 1994. Stressor-specific induction of heat shock proteins in rat hepatoma cells. Toxicology, 94, 143-159.

Zhao, F., Mayura, K., Hutchinson, R.W., Lewis, R.P., Burghardt, R.C., Phillips, T.D., 1995. Developmental toxicity and structure-activity relationships of chlorophenols using human embryonic palatal mesenchymal cells. Toxicol. Lett., 78, 35-42.

Zhao, Y.H., Ji, G.D., Cronin, M.T.D., Dearden, J.C., 1998. QSAR study of the toxicity of benzoic acids to Vibrio fisheri, Dapnnia magna and carp. Sci. Total Environ., 216, 205215. 
Zou, J., Salminen, W.F., Roberts, S.M., Voellmy, R., 1998. Correlation between glutathione oxidation and trimerization of heat shock factor 1, an early step in stress induction of the Hsp response. Cell Stress and Chaperones, 3, 130-141. 


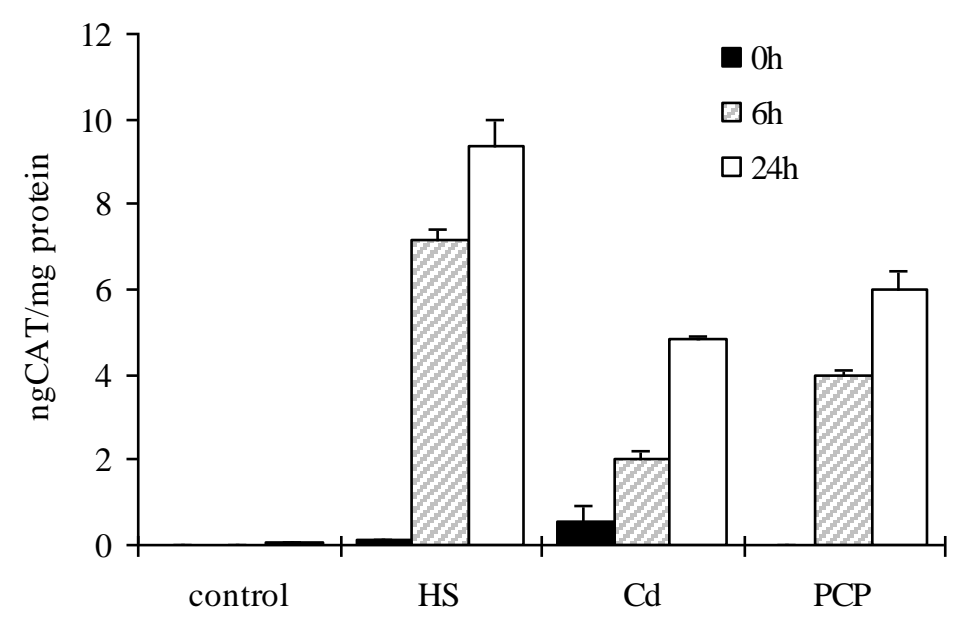

Figure 1. hsp70-CAT activation after exposure to heat (HS, $42^{\circ} \mathrm{C}, 45 \mathrm{~min}$ ) or chemical $(\mathrm{CdCl} 2,0.5 \mu \mathrm{M}$ or PCP, $100 \mu \mathrm{M}$ for $16 \mathrm{hrs})$ stress. Cells were allowed to recover for 0,6 and $24 \mathrm{hrs}$ after stress. $\mathrm{n}=3$ cultures per treatment (mean \pm standard deviation). 

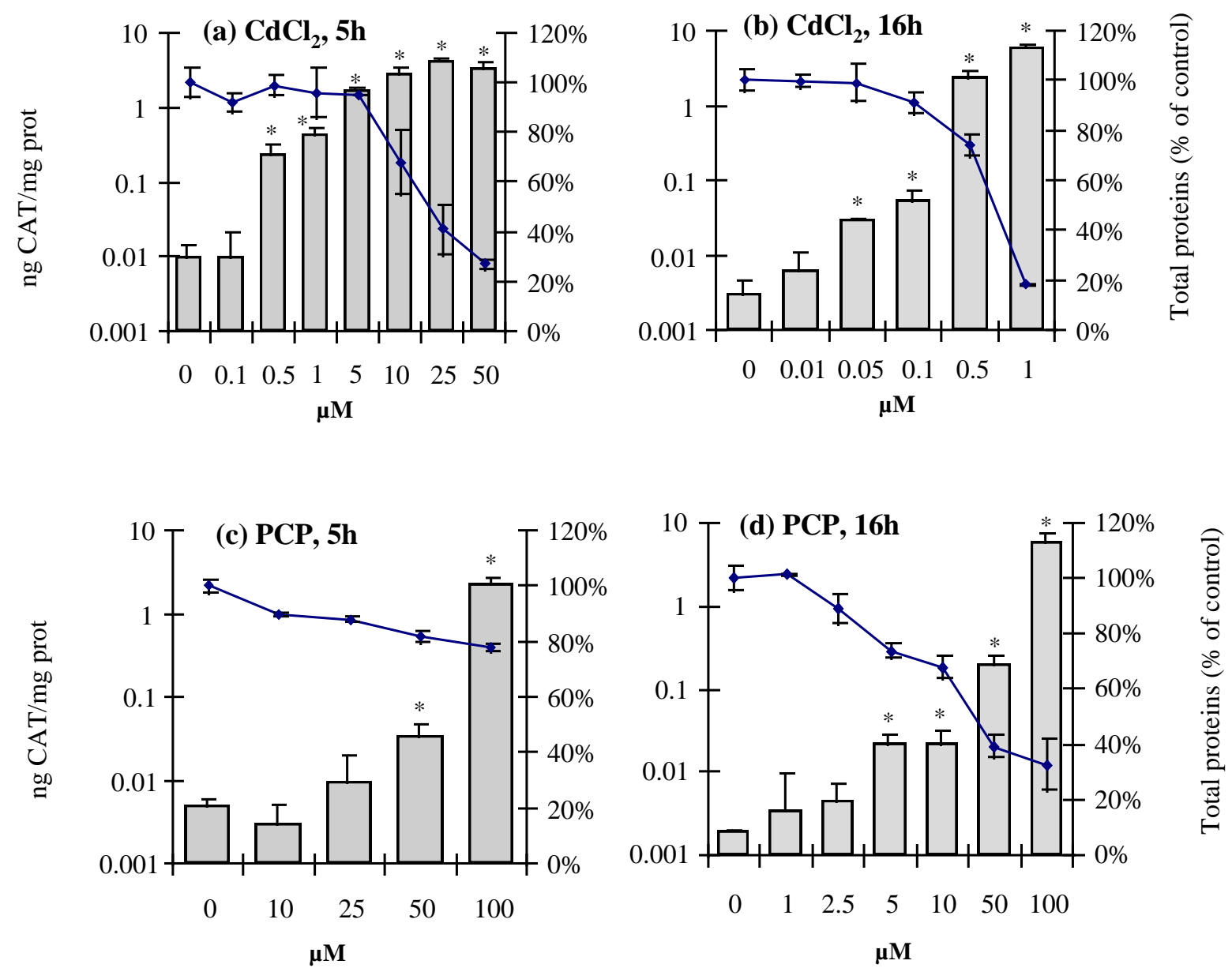

Figure 2. Dose-effect relationships of chemical hsp 70 activation. Cells were exposed for 5 hrs $(\mathrm{a}, \mathrm{c})$ or $16 \mathrm{hrs}(\mathrm{b}, \mathrm{d})$ to either $\mathrm{CdCl}_{2}$ or PCP. Accumulation of CAT protein was detected after a $24 \mathrm{hr}$ recovery period. Results represent at least three independent experiments; $n=3$ wells per concentration (mean \pm standard deviation). *: significant induction $(\mathrm{p}<0.05)$. Bars: ngCAT/mg protein (left ordinate, $\square$ ); curves: cytotoxicity, expressed as percentage of total proteins (right ordinate, $\rightarrow$ ). 


\begin{tabular}{|c|c|c|c|c|c|c|c|c|c|c|}
\hline \multirow[b]{2}{*}{ Metals } & \multirow[b]{2}{*}{$\mu \mathrm{M}$} & \multicolumn{9}{|c|}{ hsp70 induction (pg CAT/mg prot.) } \\
\hline & & 0 & 0,1 & 0,5 & 1 & 5 & 10 & 25 & 50 & 100 \\
\hline $\mathrm{CdCl}_{2}$ & & 5 & 5 & 240 & 446 & 1709 & 2847 & 6394 & 3445 & \\
\hline $\mathrm{HgCl}_{2}$ & & 4 & / & / & 8 & 11 & 24 & 5639 & 2574 & \\
\hline \multirow[t]{3}{*}{$\mathrm{ZnSO}_{4} .7 \mathrm{H}_{2} \mathrm{O}$} & & 1 & l & I & 5 & 6 & 8 & I & 24 & 1340 \\
\hline & & & \multicolumn{8}{|c|}{ Total Proteins (\% of control) } \\
\hline & $\mu \mathrm{M}$ & & 0,1 & 0,5 & 1 & 5 & 10 & 25 & 50 & 100 \\
\hline $\mathrm{CdCl}_{2}$ & & & 95 & 99 & 96 & 95 & 68 & 41 & 27 & \\
\hline $\mathrm{HgCl}_{2}$ & & & / & / & 98 & 92 & 104 & 71 & 10 & \\
\hline $\mathrm{ZnSO}_{4} \cdot 7 \mathrm{H}_{2} \mathrm{O}$ & & & / & / & 108 & 99 & 99 & l & 99 & 84 \\
\hline
\end{tabular}

Table 1. hsp70 promoter induction and cytotoxicity after a $5 \mathrm{hr}$ exposure to heavy metals. Cells were harvested after a $24 \mathrm{hr}$ recovery period. Results represent three or more identical experiments made in triplicate. Significant inductions $(\mathrm{p}<0.05)$ are in boldface. /: not determined. 


\begin{tabular}{|c|c|c|c|c|c|c|c|c|c|c|c|}
\hline \multirow[b]{2}{*}{ Chemicals } & \multirow[b]{2}{*}{$\mu \mathrm{M}$} & \multicolumn{10}{|c|}{ hsp70 induction (pg CAT/mg prot.) } \\
\hline & & 0 & 1 & 5 & 10 & 25 & 50 & 100 & 250 & 500 & 1000 \\
\hline PCP & & 6 & 9 & 19 & 22 & I & 193 & 6507 & 0 & & \\
\hline 2,4,5-TCP & & 1 & / & / & 10 & I & 24 & 151 & 2231 & & \\
\hline 3,5-DCP & & 0 & / & / & 3 & 1 & 3 & 34 & 1156 & & \\
\hline 2,4-DCP & & 0 & I & / & 0 & 0 & 3 & 9 & 568 & & \\
\hline 4-CP & & 4 & I & / & 3 & l & 3 & 1 & 2 & 24 & 20 \\
\hline Phenol* & & 2 & / & / & I & / & 7 & 5 & 2 & 13 & 27 \\
\hline TCHQ & & 11 & 11 & 9 & 15 & 113 & 440 & 313 & $439^{a}$ & & \\
\hline CDNB & & 10 & 13 & 22 & 133 & 6 & 0 & & & & \\
\hline parathion & & 0 & I & I & 0 & 0 & 0 & 6 & $36 S$ & $25 S$ & \\
\hline 3,4-DCA & & 3 & 2 & / & 0 & I & 7 & 9 & $25^{a}$ & $\mathbf{3 8}^{b}$ & \\
\hline $2,4-\mathrm{D}$ & & 0 & 2 & / & 3 & / & 4 & 21 & / & 0 & \\
\hline $\mathrm{B}(a) \mathrm{P}$ & & 9 & 9 & 13 & 5 & 10 & 15 & $S$ & & & \\
\hline nonylphenol & & 7 & 5 & 7 & 19 & 5 & 0 & 0 & & & \\
\hline endosulfan & & 0 & 0 & 0 & 0 & 0 & & & & & \\
\hline \multirow[t]{3}{*}{ diuron } & & 0 & I & / & 0 & 0 & 0 & 0 & 0 & 0 & \\
\hline & & & \multicolumn{9}{|c|}{ Total Proteins (\% of control) } \\
\hline & $\mu \mathrm{M}$ & & 1 & 5 & 10 & 25 & 50 & 100 & 250 & 500 & 1000 \\
\hline PCP & & & 101 & 81 & 65 & l & 41 & 24 & 0 & 0 & \\
\hline 2,4,5-ТCP & & & 104 & / & 102 & l & 58 & 43 & 8 & 0 & \\
\hline 3,5-DCP & & & 100 & / & 110 & 108 & 76 & 66 & 28 & 0 & \\
\hline $2,4-\mathrm{DCP}$ & & & 106 & / & 106 & 99 & 85 & 67 & 49 & 0 & \\
\hline $4-\mathrm{CP}$ & & & I & / & 92 & / & 88 & 86 & 81 & 76 & 43 \\
\hline Phenol* & & & / & I & / & / & 97 & 89 & 67 & 20 & 13 \\
\hline TCHQ & & & 100 & 108 & 101 & 112 & 85 & 62 & 33 & 0 & \\
\hline CDNB & & & 107 & 105 & 88 & 5 & 3 & & & & \\
\hline parathion & & & I & I & / & 92 & 88 & 81 & 90 & 79 & \\
\hline 3,4-DCA & & & 108 & / & 108 & / & 107 & 94 & 94 & 84 & \\
\hline $2,4-\mathrm{D}$ & & & 101 & I & 95 & l & 102 & 103 & I & 65 & \\
\hline $\mathrm{B}(a) \mathrm{P}$ & & & 91 & 91 & 89 & 86 & 89 & / & & & \\
\hline nonylphenol & & & 105 & 96 & 64 & 21 & 9 & 0 & & & \\
\hline endosulfan & & & 102 & 99 & 90 & 4 & & & & & \\
\hline diuron & & & l & / & 99 & 100 & 95 & 79 & 13 & 0 & \\
\hline
\end{tabular}

Table 2. $h s p 70$ promoter induction and cytotoxicity after a $16 \mathrm{hr}$ exposure to various organic chemicals. Cells were harvested after a $24 \mathrm{hr}$ recovery period. Results represent three or more identical experiments made in triplicate. Significant inductions $(p<0.05)$ are in boldface. *: the concentrations tested are ten fold those indicated. $a: 200 \mu \mathrm{M} ; b: 300 \mu \mathrm{M}$. $S$ : solubility problems were observed. /: not determined. 


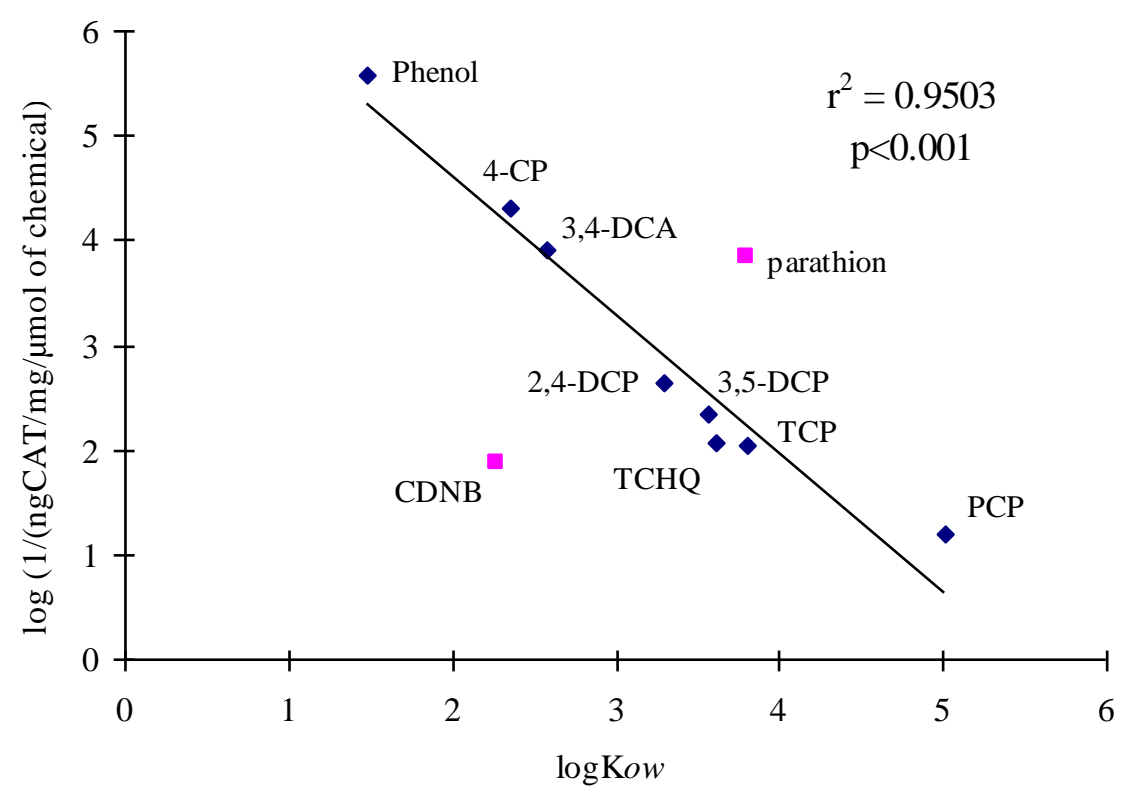

Figure 3. Correlation between $h s p 70$ induction and the octanol-water partition coefficient $\left(\log \mathrm{K}_{o w}\right)$ for some of the effective chemicals. In the graph, CDNB and parathion are not included into the linear regression. When they are included, the correlation coefficient value of the regression becomes $\mathrm{r}^{2}=0.5336$. 